\title{
Impact of a major cardiovascular surgical procedure on patients' interests for advance care planning
}

F Gigon ${ }^{1,2^{*}}$, C Combescure ${ }^{1}$, P Merlani ${ }^{2,3}$, B Ricou ${ }^{1,2}$

From ESICM LIVES 2015

Berlin, Germany. 3-7 October 2015

\section{Introduction}

Advance directives (AD) and/or a health care surrogate decision maker (HCS) are potentially helpful for caregivers to respect the patients' autonomy whenever their competence is affected. Patients planned for major cardiovascular surgical procedure requiring intensive care may consider $\mathrm{AD} / \mathrm{HCS}$ as important or necessary because of the coming exposure to a potential life-threatening situation.

\section{Objectives}

To investigate whether a major cardiovascular surgical procedure requiring intensive care impacts on patients', interests for $\mathrm{AD} / \mathrm{HCS}$.

\begin{tabular}{l} 
Table: Impact of a major cardiovascular surgery on patients' interests for advance care planuing \\
\cline { 3 - 7 } \multicolumn{1}{c|}{} \\
\cline { 3 - 7 }
\end{tabular}

Figure 1 Figure legends: $\mathrm{p}^{\circ}: \mathrm{Chi}^{2}, \mathrm{p}^{*}: \mathrm{Mc}$ Nemar, l: NA

'University Hospitals of Geneva, Geneva, Switzerland

Full list of author information is available at the end of the article

(c) 2015 Gigon et al.; This is an Open Access article distributed under the terms of the Creative Commons Attribution License (http:// creativecommons.org/licenses/by/4.0), which permits unrestricted use, distribution, and reproduction in any medium, provided the original work is properly cited. 


\section{Methods}

Patients planned for major cardiovascular surgery were randomized either to a group $\mathrm{A}(\mathbf{g A})$ met the day before and after ICU discharge, or to a group B (gB) met only after ICU discharge. At each meeting, they were interviewed according to the same questionnaire.

\section{Results}

361(89\%) patients (of 405 eligible) were interviewed. Male: $256(71 \%)$; age(mean \pm SD):68 \pm 15 years. 95(27\%) had a last will, $77(21 \%)$ a life insurance, $119(33 \%)$ a funeral plan and $43(12 \%)$ an organ donor card. $181(50 \%)$ patients were randomized in the gA, 180(50\%) in the gB.

After surgery, 164(91\%) of the gA patients remembered the interview - before, $90(50 \%)$ what $\mathrm{AD}$ are and $61(34 \%)$ could give a correct definition of AD.

\section{Conclusions}

Few patients, even when scheduled for major surgical procedure, knew what AD or HCS are and even fewer had AD/HCS. Their incidence was much lower than other plans for the future (last will, life insurance, etc.). Undergoing major surgery requiring intensive care modified significantly the attitudes of patients towards AD/HCS, decreasing their interest. Further analyses regarding these patients' reasons for or against AD/HCS will provide more information to understand the rarity of advance care planning.

\section{Grant Acknowledgment}

This study is sustained by the FNRS (CR31I3_127135/1).

\section{Authors' details}

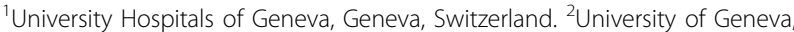

Geneva, Switzerland. ${ }^{3}$ Ospedale Regionale di Lugano, Lugano, Switzerland.

Published: 1 October 2015

\section{doi:10.1186/2197-425X-3-S1-A650}

Cite this article as: Gigon et al:: Impact of a major cardiovascular

surgical procedure on patients' interests for advance care planning.

Intensive Care Medicine Experimental 2015 3(Suppl 1):A650.

\section{Submit your manuscript to a SpringerOpen ${ }^{\circ}$ journal and benefit from:}

- Convenient online submission

- Rigorous peer review

- Immediate publication on acceptance

- Open access: articles freely available online

- High visibility within the field

- Retaining the copyright to your article

Submit your next manuscript at $>$ springeropen.com 